\title{
Espaços da destituição e as políticas urbanas e regionais no Brasil: uma visão panorâmica
}

\author{
Spaces of destitution, and urban and regional policies in Brazil: a panoramic view
}

Carlos Antônio Brandão

Universidade Federal do Rio de Janeiro

\begin{abstract}
The objective of this article is to recoup and present a comprehensive view, of collective and wide timeframe on the structure and dynamics of the urbanization process in Brazil, seeking to synthesize the varied rounds of regulatory experimentation and changes in institutional landscapes in which attempts have been made as to regulate it through urban and regional policies. There has been an expanding, precarious and low-intensity process of urbanization of the sociopolitical forces that structures it, which owns its power to the control of land ownership. Varied attempts to discipline and regulate this control and the speculative urban accumulation have had little success. In recent decades, the circuits of this accumulation have modernized, conglomerated and financialized. Throughout the analyzed period, social struggles of resistance and the activism of social movements have been in action, and are expected to widen with the new conflicts of the current and future urban scene.
\end{abstract}

\section{Keywords}

Brazil; urbanization; regulatory experimentation; urban and regional planning.

JEL Codes O18; R58; O43; R38.

\section{Resumo}

O objetivo deste artigo é realizar uma recuperação ampla e apresentar uma visão abrangente, de conjunto e de largo horizonte temporal, sobre a estrutura e a dinâmica do processo de urbanização no Brasil, procurando sintetizar as variadas rodadas de experimentação regulatória e as mudanças nas paisagens institucionais em que se desenrolaram tentativas de disciplinamento e regulação das forças e interesses patrimoniais-mercantis por meio de politicas urbanas e regionais e reescalonamentos estatais. Constata-se um processo de urbanização expansiva, precarizada e de baixa intensidade de regulação das forças sociopoliticas que o estrutura, que tem seu poder no controle da propriedade da terra. Variadas tentativas de disciplinar e regular esse controle e a acumulação urbana especulativa tiveram pouco êxito. Nas últimas décadas, os circuitos dessa acumulação se modernizaram, conglomeraram e financeirizaram. Durante todo o periodo analisado, lutas sociais de resistências e o ativismo dos movimentos sociais estiveram em ação e espera-se que devam se ampliar com os novos conflitos na cena urbana atual e futura.

\section{Palavras-chave}

Brasil; urbanização; experimentações regulatórias; politicas urbanas e regionais.

Códigos JEL O18; R58; O43; R38. 


\section{Introdução}

País continental e heterogêneo, das desigualdades e das diversidades, o Brasil apresenta, entre suas características mais marcantes, o seu peculiar e contraditório processo de urbanização, que possui uma tripla natureza: a primeira é a que se estruturou, ao longo de sua história, uma "máquina" expansiva e potente de produção de cidades. A segunda é a que esta produção social e disputada do ambiente construído tem as marcas da destituição e da precariedade. A terceira, é a que a regulação sociopolítica deste processo de urbanização espraiador e excludente foi e é fraca ou inexistente.

Nesse contexto, é decisivo o debate sobre as especificidades de nossa estruturação territorial e de nosso particular processo de urbanização e as tentativas, em grande medida fracassadas, de promover uma regulação através de políticas públicas, ações e experiências de planejamento urbano-regionais.

O Brasil ergueu, em um processo de longa duração, uma sociedade urbana de massas complexa, sem urbanidade, fruto da produção de espaços urbanos precarizados e ilegais, com interdição do direito à cidade para a maioria e sob o controle férreo de elites fundiárias, imobiliárias e rentistas urbanas e rurais, pouco submetíveis ao disciplinamento dos poderes públicos e desígnios coletivos.

O objetivo deste artigo é apresentar uma visão abrangente, de conjunto e de largo horizonte temporal, sobre a estrutura e a dinâmica desse processo e das experimentações e paisagens institucionais em que se desenrolaram tentativas de sua regulação por meio de políticas urbanas e regionais.

O Brasil montou uma economia urbana moderna, com sofisticada estrutura reprodutiva diferenciada (composta por variadas frações de classes sociais), estrutura produtiva diversificada (industrial, agropecuária e terciária) e heterogeneidades estruturais (sociais, regionais, rurais e culturais) marcantes.

Complexos processos, de longo curso e de natureza contraditória, tiveram as marcas da fuga para a frente expansiva do dinamismo econômico, dos efeitos de multiplicação e aceleração da renda e da riqueza, mas também tiveram as marcas da interdição estrutural e dos travamentos conjunturais recorrentes das reformas sociais, da distribuição da renda e da habilitação pela propriedade e pelo acesso aos direitos, para a maioria da sociedade.

A resultante é uma urban growth machine, no contexto periférico e subdesenvolvido do capitalismo mundial, formada por uma coalizão de for- 
ças sociais, sob o domínio despótico de elites que têm uma de suas bases fundantes de poder no controle irrestrito da terra. $\bigcirc$ arco de aliança em torno do ambiente construído brasileiro é amplo, sendo comandado por variados apropriadores de rendas fundiárias (patrimonialistas), de diversas naturezas, que se encontram articulados a outros apropriadores de rendimentos de outras fontes. Entre essas últimas fontes, cabe destaque às mercantis e usurárias, conduzindo a uma sobredeterminação dos circuitos da órbita da circulação de riqueza velha coagulada (rentistas e especulativos) que se superpõe à órbita da produção empreendedora de riqueza e capacidade produtiva nova. Uma característica mais geral de todas essas fontes de renda é sua relação estreita com os fundos públicos.

Se esta é uma coalizão secular - com as alianças mercantis-fundiárias detendo um poder concentrado que atravessa relações de Estado, estatalidades e canais de representação de interesses - caberia investigar suas formas de modernização e reacomodação em cada momento conjuntural no Brasil.

Desde a virada para o século XXI, os circuitos da acumulação urbana se modernizaram, conglomeraram e financeirizaram. As formas através das quais os agentes promotores da expansão urbana se articulam se sofisticaram, e a nova morfologia de organização dos empreendimentos e de seu financiamento exige pesquisas acuradas.

Cabe advertir, entretanto, que a entrega mais direta dos espaços urbanos para os apropriadores de rendas fundiárias-imobiliárias e sua moldagem aos lucros privados não se deu sem contestação e lutas sociais contra-hegemônicas, com o potente acúmulo de resistências e de diversas manifestações de ativismo por parte dos movimentos sociais urbanos ao longo desta história.

Em um país continental, moldou-se uma urbanização paradoxal, com metropolização e concentração, interiorização e espraiamento, com centros regionais intermediários e uma miríade de cidades locais-pequenas-quase-rurais. $O$ que tem em comum é que todos esses portes de cidade parecem reproduzir as mazelas sociais e a destituição de direitos à maioria de suas respectivas populações.

Podemos constatar processos muito específicos de desenvolvimento desigual em qualquer uma das dimensões em que se queira jogar luz sobre nossas variadas desigualdades e injustiças internas (amálgama e sobreposição de iniquidades sociais, de não acesso a direitos; heterogêneas estru- 
turas econômicas etc.), e vigorosas variedades-diversidades (ambientais, sociais, culturais etc.).

Em todos estes longos processos, o papel do Estado foi decisivo. Portanto, no Brasil, o debate sobre sua natureza e suas formas específicas de reescalonamento jurisdicional-espacial deveriam ser aprofundados, buscando discutir as especificidades de nosso pacto territorial-federativo de poder e sua capacidade governativa, com as características congênitas de baixa intensidade, dotadas de um travamento sistêmico às tentativas de regulação e disciplinamento, sobretudo do poder fundiário e imobiliário.

$O$ intenso processo de crescimento histórico-geográfico desigual acentuou-se ainda mais durante os séculos XX e XXI, com a concentração espacial de sua população e de sua riqueza material em uma restrita porção territorial, basicamente no litoral e no Centro-Sul.

Políticas territoriais em diversos momentos foram experimentadas. Principalmente a partir da segunda metade do século XX, várias rodadas de concepção e implementação (interditada) de planejamento urbano e regional foram levadas a cabo.

Este texto, após esta introdução, esquematiza a experiência brasileira de urbanização no contexto mais geral da mudança social e da produção socioespacial e discute as tentativas de regulação com políticas urbanas e territoriais em diversos ciclos históricos.

\section{Cem anos de urbanização precarizada (1920/2020) e as tentativas de sua regulação}

Estamos para completar um século de urbanização e podemos constatar que esta foi uma história de uma espécie de amálgama de disparidades, convivência do variado, de extensividade, itinerância e de fuga para a frente expansiva, mas também de produção de um ambiente construído com ocupação precarizada de espaços com irregularidade, exclusão e ilegalidade (Faria, 1978, 1991; Costa; Mendonça, 2008; Maricato, 2011, 2015).

De uma sociedade rural, em que, em 1920, apenas $16 \%$ do total dos 30 milhões de habitantes existentes no Brasil viviam em centros urbanos, construímos uma complexa sociedade urbana, com duas centenas de milhões de pessoas morando nas cidades. A concentração espacial é uma das marcas desta sociedade. As capitais abrigam 1/4 da população total do 
país. Em apenas 25 regiões metropolitanas residem 87 milhões de habitantes, representando $43 \%$ da população total.

A periodização proposta aqui é apenas uma tentativa e ilustrativas ilustra a longa duração desses processos socioespaciais. Podemos recortar a década de 1920, tanto como uma primeira onda ou camada sedimentar do processo urbanização - enquanto diversificação econômica e diferenciação social, isto é, a incipiente estruturação de uma "sociedade urbana" -, quanto um primeiro momento da inicial consolidação do urbanismo enquanto campo do conhecimento e também a origem das primeiras conscientizações, preocupações e as pioneiras experimentações de intervenção nos espaços urbanos em expansão.

Inspirando-nos em Francisco de Oliveira, seria importante buscar alinhavar as especificidades desta urbanização, alertando-se que

a proposição não deveria ser a de buscar um estatuto próprio para o urbano, mas, ao contrário, procurar determinar concretamente este urbano (...) saindo da generalidade e da tipologia, entender o que é que de específico existe neste urbano (...) determinar como o espaço socialmente produzido se põe a serviço da acumulação de capital (Oliveira, 1979, p. 14-15 - grifos meus).

Averiguar em projetos coletivos de investigação como se ergueu, com enorme rapidez e conservadorismo, uma das sociedades urbanas de massa mais complexas e desiguais do planeta. Uma história de dinâmica máquina de crescimento (econômico-espacial), simultaneamente espalhada, circunscrita, seletiva e encravada (setorial e espacialmente). Uma rede urbana paradoxalmente concentrada e dispersa ao mesmo tempo. Uma sociedade multicultural vivendo em uma economia urbana simultaneamente moderna, de "fuga para a frente" (territorial e dos direitos), excludente, de predação ambiental e social.

Cabe lembrar que ao longo de setenta anos (1920/1990) se forjou e evoluiu um vigoroso processo de industrialização, acelerado a partir da segunda metade do século XX, que conduziu o Brasil a ingressar no agrupamento seleto de dezena das nações com os maiores níveis de desenvolvimento das forças produtivas capitalistas materiais modernas, dotadas de sistemas industriais "completos".

Nesse período, sobretudo nos anos entre 1940 e 1980, processaram-se intensos fluxos migratórios; expansiva urbanização, que combina concentração e dispersão; potente integração e nacionalização dos mercados (de bens, de trabalho e de consumo); com diferenciação e sofisticação das classes sociais, sobretudo da fração média. 
Ao mesmo tempo, ocorreu insurgência de lutas políticas, enriquecimento regionalizado dos valores culturais, estruturação de um pacto federativo sui generis, provisão massiva de bens e serviços públicos (porém insuficientes e sem qualidade adequada), entre outros fenômenos bastante desafiadores para a legitimação de uma estratégia nacional de desenvolvimento.

Todos esses foram processos rápidos e intensos que se entrecruzaram e amalgamaram para forjar uma nação em construção (cíclica e conjunturalmente interrompida) sobre um território continental, heterogêneo, que atingiu algumas das maiores taxas de crescimento econômico da história do capitalismo.

Apesar dessas e outras fragilidades, o sistema econômico nacional, configurado no século XX, mesmo dependente-periférico-subdesenvolvido, alcançou elevado grau de integração comercial e produtiva interna, dotando o Brasil de uma ampliada rede matricial de relações intra e inter-ramos econômicos (cópia incompleta da primeira e da segunda revoluções industriais). Aquele sistema ou estilo de crescimento se estruturou no Sudeste, desceu para o Sul e subiu o litoral Leste, pela ação das forças inerciais e centrípetas que cumulativamente exerceram efeitos polarizados nas regiões com maior agrupamento e densidade socioeconômica, diversificação produtiva e diferenciação social, com sobreposição do processo de reprodução e da órbita da circulação sobre a produção.

Ou seja, a valorização dos capitais "domésticos" não-industriais é ponto crucial para o entendimento das particularidades de nossa produção socioespacial. Ao longo da história, esses capitais sobreviveram econômica e politicamente ancorados em um pacto singular de órbitas e circuitos reprodutivos patrimonialistas e rentistas, tendo sua força especulativa e de preservação de riqueza envelhecida, tendo sido, recorrentemente, sancionada e legitimada pelo Estado brasileiro. $O$ alicerce de seu poder político radica na intermediação mercantil e na manutenção da estrutura de distribuição de propriedade da terra intacta, não sendo tolerados mecanismos de regulação fundiária. Em termos gerais, pode-se afirmar que o Brasil é marcado pela participação decisiva de empresas estrangeiras e pela presença de formas de capitais dispersas e heterogêneas, difíceis de serem aglutinadas, o que exacerba a complexidade econômica, política, social e territorial do país.

Ao longo da história do deslocamento de cidades "expansivas", de virtual urbanização total (Castriota, 2016), que crescem para fora e nunca para dentro. Massas redundantes de capital se dirigiram para formas de 
preservação da riqueza assentadas na retenção especulativa da terra e no acúmulo de direitos de propriedade privada que concedem licença para a extração de substanciais rendas fundiárias e monetárias que travam o acesso da maioria da população ao direito à cidade.

O arco de alianças da produção do urbano brasileiro é híbrido e amplo, lembrando uma composição entre "máquina de crescimento", de Logan e Molotch (1987) e "empreendedorismo urbano", de Harvey (2005).

Aquela aludida máquina de produção de urbanos marcados pelas desigualdades também foi a promotora de um pacto conservador de produção do espaço urbano e de uma coalizão de interesses das frações mercantis, fundiárias, imobiliárias altamente lucrativo e travador do acesso à urbanidade e aos direitos.

Desde esse início do século XX, mas sobretudo no período após a década de 1930, foram sendo realizadas intervenções estéticas, físicas e sanitárias, e dos planos de remodelagem, melhoramentos e embelezamentos dos períodos anteriores transita-se para uma abordagem cientificista dos problemas urbanos, colocados como carência de intervenção técnica.

Do ponto de vista científico e das ideias que influenciaram as intervenções naquele início e até meados daquele século, cabe destaque para as concepções teóricas da Escola de Chicago, que discutiram, entre muitas outras questões, a dificuldade de absorção dos habitantes que chegavam às cidades e as dificuldades de sua plena integração.

Após essa fase, o Brasil viveu uma longa e importante rodada de experimentação institucional, com a modernização varguista do setor público e sua peculiar provisão de serviços coletivos, com políticas concebidas na escala nacional. Seria o período de gênese do que se vem denominando na literatura internacional - há contribuições sobre esse tema, por exemplo, de Jessop (2006) e Brenner et al. (2012) - de Estado Nacional de Bem-Estar Keynesiano (KNWS).

Os períodos Vargas, JK e do golpe militar têm uma constância que é a busca e a crença em uma normatização racionalizadora, com a qualificação de burocracias e o uso de técnicas de planificação com o objetivo de alcançar o disciplinamento das forças políticas e econômicas que produziam os espaços urbanos e regionais (Villaça, 1999; Monte-Mór, 2008).

Frente às preocupações com a acelerada urbanização e o agravamento das desigualdades inter-regionais que a industrialização concentrada e a integração do mercado nacional vieram explicitar, variadas experimentações 
institucionais ocorreram, com a criação de vários órgãos de planejamento em nível federal. Algum reescalonamento estatal ocorrerá, com defasagem temporal de alguns anos, pois, no nível estadual e até no municipal de grande porte também se replicarão instituições semelhantes, buscando uma racionalidade técnica aos problemas espaciais do país.

No contexto do pós-guerra, do debate sobre teorias e estratégias de desenvolvimento em porções territoriais marginalizadas ou em defasagem, da divulgação das experiências de intervenção regional - como a criação das instituições Tennessee Valley Authority - TVA (1933) e Cassa per il Mezzogiorno (1950), o Brasil pode acumular vasto aporte conceitual, metodológico e prático na busca por criar instituições que pudessem combater as diversas formas e as dimensões das desigualdades e heterogeneidades estruturais daqueles tipos de territórios.

Assim foram criadas a Comissão do Vale do São Francisco - CVSF, em 1948; A Superintendência do Plano de Valorização Econômica da Amazônia - SPVEA, em 1952; a Superintendência do Desenvolvimento da Amazônia - Sudam, em 1966; a Superintendência do Desenvolvimento do Centro-Oeste - Sudeco, em 1967, e no mesmo ano, a Superintendência do Desenvolvimento da Região Sul - Sudesul. Entretanto, a que ganharia maior destaque seria a criação da Superintendência do Desenvolvimento do Nordeste - Sudene, em 1959, a partir dos estudos e proposições de Celso Furtado no GTDN. Todas essas instituições foram criadas com o objetivo declarado de promoção do desenvolvimento e planejamento regional e de articulação e coordenação das ações federais em suas respectivas regiões.

A Sudene teria um papel relevante e inovador, sobretudo no período 1959 e 1964, para em seguida se transformar crescentemente em um órgão esvaziado politicamente e mero repassador dos recursos dos incentivos fiscais dirigidos sobretudo aos empresários extrarregionais. De um diagnóstico de acionar e mobilizar recursos, ativos e capacitações nordestinas em uma estratégica abrangente de coordenação e desenvolvimento de longo prazo, a Sudene deixa de ser uma superintendência de fato, para ser a gestora de um instrumento do repasse dos recursos do sistema de incentivos 34/18.

Quanto aos problemas especificamente urbanos, o que se viu foi uma concepção de tratá-los pela perspectiva mais imediata e angariadora de legitimação nas massas populares: uma organização pela via da provisão 
de unidades de habitação e não pela perspectiva do desenvolvimento e do planejamento do conjunto da cidade.

Assim foi criada a Fundação da Casa Popular, em 1946, que produziu apenas cerca de 20 mil casas durante toda sua existência. Quando se acrescenta as construídas pelos Institutos de Previdência e pelas Caixas Econômicas, alcança-se no máximo 120 mil habitações em vinte anos (Marchi, 2015).

No plano das ideias, no final dos anos 1960 e início dos 1970, estruturou-se um campo de conhecimento que poderia ser denominado de urbanismo e economia política da urbanização, no qual, procurando criticar a hegemonia teórica da Escola de Chicago, alguns autores apontaram importantes questões sobre a reprodução social no espaço urbano. Essa concepção crítica do ambiente construído de forma disputada pelas frações de classes sociais será central para os debates e para a organização política em torno da bandeira da reforma urbana na década seguinte.

Destaque-se nesse sentido a organização do Seminário de Habitação e Reforma Urbana, que teve lugar no Hotel Quintandinha, promovido pelo Instituto dos Arquitetos do Brasil - IAB, em Petrópolis, em 1963, demarcando um primeiro esboço de uma visão crítica sobre o espaço urbano brasileiro e a necessidade de sua transformação sociopolítica, via reforma urbana. $O$ evento teve

ampla divulgação, na tentativa de oferecer subsídios para uma atuação estatal efetiva no setor. Os participantes discutiam, então, em torno do conceito de "reforma urbana", detendo-se na necessidade de regulações do uso do solo urbano, das construções e investimentos setoriais, numa tentativa de ação integrada para o controle estatal do espaço urbano (Monte-Mór, 2008, p. 45)

Entretanto, apesar dessas lutas, "o problema urbano permaneceu centrado na habitação e só gradativamente foram incorporados os aspectos ligados à infraestrutura urbana e ao próprio planejamento urbano e metropolitano" (Monte-Mór, 2008, p. 45).

Qualquer periodização sobre nossa história e suas especificidades sociais, econômicas e políticas deve realizar um corte temporal em 1964. Para o estudo da dinâmica de nossa sociedade urbana é preciso lembrar certas determinações e condicionantes impostos no período 1964-1985.

Em 1964 terá início a institucionalização do SERFHAU (Serviço Federal de Habitação e Urbanismo) e do Banco Nacional de Habitação (BNH), e a disseminação de um tratamento tecnocrático, centralizado e inadequado à realidade concreta da problemática da rápida e "caótica" urbanização, que 
foi analisado minuciosamente por vasta literatura, dada sua centralidade no debate acerca da natureza da urbanização brasileira (Monte-Mór, 2008; Maricato, 2011; Rolnik, 2015).

Criou-se em 1966 um sistema de poupança compulsória, o FGTS, que veio a se juntar à poupança voluntária, para dirigir adequado crédito para a provisão habitacional, mas teve dificuldade de atender justamente a população de mais baixa renda, que deveria ser o foco da política segundo o propugnado nos documentos oficiais. Um relatório constatava que, depois de 10 anos, o BNH continuava a destinar somente $20 \%$ das casas que ele financiou para o público de baixa renda.

Em 1967, foi criado o Ministério do Interior, incorporando o SERFHAU e o BNH. Em 1971, o BNH se transforma em banco de segunda linha, isto é, tão-somente repassa recursos e responsabilidades aos agentes privados. Até 1973 ele financiou cerca de um milhão de moradias. Seria extinto em 1986. O balanço das realizações do banco demonstra que ele acabou promovendo a expansão para fora, para as franjas da cidade, dotadas de deficiente infraestrutura, não enfrentando as questões estruturais de agir no conjunto da cidade e regular a especulação fundiária e imobiliária, centrais para a provisão adequada de morada, sobretudo à população de menor renda. Do ponto de vista regional, tinha concentrado a provisão habitacional nas regiões mais desenvolvidas do país.

Importante destacar nesse contexto histórico que descrevemos o papel central da falta de democracia para o enfrentamento de problemas tão abrangentes e conflituosos. A destruição do estado democrático de direito, perpetrada pelo Golpe de 1964, acabou por devastar estruturalmente a política e a formação de quadros e despolitizar as relações políticas no Brasil. O regime autoritário de vinte anos desmantelou a esfera política, o espaço público, as bases democráticas, destituindo de fala e direitos, e mesmo invisibilizando, as forças populares nos centros de decisão.

O arbítrio e a brutalidade desarticularam a construção de cidadania que vinha se estruturando, provocaram o ocaso das arenas e dos espaços de concertação e de diálogos. Impediu a formação de lideranças e de novos quadros políticos e despolitizou permanentemente a sociedade brasileira. Sem a mediação democrática dos conflitos e sem canais institucionalizados que pudessem aglutinar e dar vazão às reivindicações, a repressão, a banalização da violência, a militarização da polícia, a opressão, a tortura e o autoritarismo, desativaram o acúmulo de direitos que vinham sendo 
perseguidos pelas forças populares e democráticas e instalaram o totalitarismo e o colapso da esfera pública.

Um aparelho de gestão pública tecnicista, autoritário e com alta centralização de decisões foi erguido durante essa modernização despótica-conservadora, que desmantelou e reorganizou administrativa e burocraticamente o Estado.

Cursos de treinamento com consultores internacionais como Brian Barry e John Friedmann e a criação de cursos de pós-graduação específicos foram implementados buscando ampliar a capacitação técnica para o tratamento das questões do planejamento urbano e regional. Será também o auge dos famosos Planos de Desenvolvimento Locais Integrados, que tinham o objetivo formal de obter alto retorno e rentabilidade dos gastos privados e públicos. Ponto importante desse período tecnocrático foi a venda de planos por consultores, a proliferação de legislações de zoneamento e o debate sobre as grandes redes de serviços públicos urbanos por empresas estatais, geralmente com uma interpretação do ambiente construído que passava pelos meros incrementos infraestruturais em rede.

Todo o planejamento autoritário deste momento partia de uma visão idealizada de cidades e regiões, buscando aplicar técnicas geralmente importadas dos grandes centros de propagação de modelos teóricos e de implementação de políticas, as quais acabavam conduzindo a intervenções tópicas e pontuais.

Em um período mais largo, poder-se-ia afirmar que a

prática recorrente nesse campo sempre foi facilitar a implantação de um projeto de modernidade urbana de curto prazo, mas de alcance limitado, constituindo-se muito mais na "produção de cenários modernizadores" do que propriamente de alterações estruturais nas cidades (Faria; Schvarsberg, 2011, p. 18 - grifos meus).

Outra marca seria a concepção de ideias "fora do lugar", desconhecendo a cidade real, portanto, propondo e implementando políticas pouco adequadas à realidade socioespacial concreta de nossas cidades e regiões (Maricato, 2011).

Enquanto os planos se multiplicavam e a regulação da terra ficava intocada, processos desigualizadores ao longo do continental território nacional reforçavam a urbanização precarizada, fragmentada e que se estende espraiadamente tornando permanente o processo de periferização, a exclusão e a segregação da maior parte da população, que não terá acesso aos frutos do progresso técnico e da modernização capitalista rápida. O que 
se processa é o "espraiamento horizontal com dispersão do tecido urbano especialmente na forma de parcelamentos precários, sem infraestrutura e irregulares do ponto de vista da legislação de uso do solo" (Faria; Schvarsberg, 2011, p. 22).

As marcas da desigualdade e da diversidade, que estiveram reiteradamente presentes na formação e no desenvolvimento brasileiro em sua dimensão territorial, se exacerbam.

Da perspectiva mais ampla do território nacional é bem conhecida a extensa literatura que tratou das flagrantes e incontestáveis desigualdades regionais brasileiras (lembremos das mais recentes: Cano, 2008; Bacelar, 2013; Diniz, 2013). Processos históricos peculiares deixaram heranças indeléveis de alta heterogeneidade nas trajetórias das cinco macrorregiões brasileiras. Além da porção Sudeste-Sul-Litoral, poderíamos afirmar que se estruturam outros três "mundos urbano-rural-regionais" muito distintos: a Amazônia; o Nordeste e o Centro-Oeste.

Em uma perspectiva histórica de longa duração, constata-se uma enorme concentração de população e riqueza material ao longo do litoral do Brasil durante séculos. Mas foi a partir das primeiras décadas do século $\mathrm{XX}$ que as soldagens econômicas inter-regionais operaram no sentido de acentuar ainda mais essa aglomeração socioespacial litorânea de pessoas e atividades, bem como a capacidade de polarização, em relação ao resto do país, desta porção territorial que denominaremos aqui de Capitalismo Sul Atlântico Brasileiro.

No período 1950/1980 o país manteve mais ou menos a mesma taxa de concentração espacial, com $43 \%$ da população total residindo na macrorregião Sudeste, dos quais quase um terço em suas duas principais regiões metropolitanas.

Os investimentos tenderam a se concentrar nessa porção regional que se afirmou enquanto enorme plataforma urbano-industrial de maior nível de desenvolvimento das forças produtivas, onde estão presentes típicos fatores de conglomeração espacial, como efeitos de vizinhança e transbordo, intensos contatos interpessoais, densas interações espaciais, indivisibilidades técnico-econômicas, externalidades transacionais e institucionais, economias de escalas, de localização e de urbanização.

Essa plataforma de mais denso desenvolvimento se estendeu ao longo dos pontos nodais da porção mais estruturada da rede urbana brasileira, sobretudo nas aglomerações metropolitanas e cidades intermediárias do 
litoral, com destaque para o Sul-Sudeste e Nordeste, ocupando pontos estratégicos do Bioma Mata Atlântica.

Tudo isso, em um contexto acelerado de crescimento econômico, seguindo os caminhos de menor resistência, o que legitimou um estilo perverso de convivência social, exclusão social e predação de pessoas, ambientes naturais, valores culturais e espaços geográficos. Em suma, em termos nacionais, e, sobretudo, durante os "cinquenta gloriosos anos" do Brasil (1933/82), solidificou-se uma sociedade de massas complexa, dispersa e amorfa.

Estruturou-se um sofisticado esquema de relações centro-periferia e hierarquias, ancorado em uma longa trajetória de junções inter-regionais e intra-regionais articulativas, que solidarizaram, pela via do mercado, as partes do país, fazendo com que os variados espaços regionais confluíssem seus projetos e coalizões de expansão em torno de uma convenção, acordo ou compromisso desenvolvimentista durável de meio século. Não obstante a força coercitiva não só concorrencial, mas também as forças coercitivas militares, repressivas, ideológicas, simbólicas e político-institucionais desempenharam papel relevante na coerência imposta que forjou (antidemocraticamente) a escala nacional. Nesse período inusitado, nossa sociedade de massas urbanas e precarizada pode conviver com altas taxas de crescimento econômico e mobilidade social intergeracional (os casos estilizados avô camponês-pai funcionário público- filho universitário) e espacial (25 milhões nas décadas 1970 e 1980).

Crescimento rápido, mas estruturalmente frágil, vulnerável e marcado pelo caráter periférico-dependente de nosso capitalismo. Desde o final dos anos 1970 "um padrão de relações centro-periferia num patamar mais alto da divisão internacional do trabalho do sistema capitalista", vem instaurando vulnerabilidades:

\begin{abstract}
expressão da contradição entre uma industrialização voltada ao mercado interno, mas financiada ou controlada pelo capital estrangeiro e a insuficiência de geração de meios de pagamento internacionais para fazer voltar à circulação internacional de capitais a parte excedente que pertence ao capital internacional (...) Agora, sob novo padrão, as crises são da circulação internacional do capital-dinheiro. (Oliveira, 1977, p. 87-88 - grifos meus)
\end{abstract}

Francisco de Oliveira, um pouco mais adiante (p. 97), vai sintetizar o período como tendo uma característica de "preparação institucional da economia para o desempenho dos oligopólios".

Não obstante, o país logrou internalizar minimamente atividades econômicas com algum controle de decisão, endogeneizando a circulação de 
parcela do excedente social gerado em sua escala nacional. Engatou suas economias regionais no contexto de uma complementaridade expansiva, que conformava um todo que "crescia junto", pois dotado de uma rede matricial de relações intra e inter-ramos econômicos. Os efeitos de multiplicação e aceleração da renda e da riqueza foram poderosos.

Este "crescimentismo", que muitos chamam de desenvolvimentismo, fez brotar sistemas urbanos econômicos e sociais metropolitanos com alta densidade demográfica, porte e adensamento de funções urbanas, integração de infraestruturas física e econômica e padrão específico de ocupação e uso do solo, com deslocamentos e assentamentos humanos peculiares e alta densidade de interações e articulações com sua hinterlândia. Expandiu as cidades médias (Sposito; Ribeiro, 2017) como detentoras de centralidades, localizadas em pontos estratégicos de variados sistema de cidades sub-regionais. Também produziu espaços rurais de alta modernização conservadora que estruturam cidades locais "do agronegócio" bastante específicas.

Como sói acontecer no Brasil,

avançar aparecia como a única solução, ainda que fosse pela via de uma valorização heterodoxamente politizada do capital. Uma valorização que, por causa de seus limites políticos, permitiu o convívio e a sobrevivência de frações e órbitas financeiras mercantis altamente especulativas, e de frações industriais e agrárias de baixa produtividade (Fiori, 2003, p. 154).

Esse amálgama de facções classiais burguesas de baixa expressão e esse desejo transformativo conduziram-se por vias e frentes expansivas de valorização e apropriabilidade privada e fuga para frente no território.

Principalmente no último quartel do século XX (destaque para o II PND 1974/1976), a ação estatal mais sistemática, em especial na periferia nacional, reforçou o papel do Estado enquanto investidor direto e estruturante do território nacional. Algumas políticas urbanas e regionais foram estruturadas.

Instituíram-se as 9 Regiões Metropolitanas em 1973/74 buscando criar um aparato de gestão e regulação, segundo uma visão de conjunto dos problemas da provisão dos serviços de interesse comum (saneamento, infraestruturas e uso do solo urbano) das maiores cidades/capitais do Brasil. Dez anos depois, a crise profunda de 1983 veio desmontar a institucionalidade e seu financiamento no tratamento das questões metropolitanas. $\mathrm{Na}$ Constituição de 1988 realiza-se o reescalonamento da problemática metropolitana para ser implementada a partir do nível dos estados da federação. 
Outro momento de reescalonamento do espaço estatal foi marcado com a institucionalização na década de 1970 dos órgãos de planejamento regional em quase todos os estados da federação. FJP, FEE, Ipardes, CEPLAB, Seade, Instituto Jones dos Santos Neves (IJSN), entre muitos outros. Pode-se dizer que esses órgãos estiveram orientados, grosso modo, pelo pensamento histórico-estrutural latino-americano, especialmente na organização de estatísticas e na realização de diagnósticos abrangentes e regionalizados das estruturas produtivas, distributivas, sociais, demográficas, fiscal-financeira no nível federativo estadual.

Uma iniciativa importante neste momento de alta concentração metropolitana, mas também de graves problemas postos pela acelerada urbanização dos principais centros urbanos regionais, ${ }^{1}$ foi a concepção do Programa Nacional de Cidades de Porte Médio, em 1976. A Política Nacional de Desenvolvimento Urbano - PNDU irá propor áreas de intervenção da política: contenção, controle, dinamização e promoção.

O processo expansivo de meio século de inserção com crescimento, no contexto internacional do pós-guerra, foi abruptamente interrompido, em 1983, depois da crise das dívidas latino-americanas. Com a crise de liquidez, a débâcle e a insolvências generalizadas, não foi possível aos países periféricos honrarem seus compromissos com os serviços da dívida externa.

Ocorreu então a confluência e a articulação de três choques: o abrupto corte de crédito internacional; a deterioração da relação de trocas e o aumento dos custos do refinanciamento dos débitos, resultando na ampliação do passivo externo, nos ajustes do setor público, na transferência de recursos ao exterior e, finalmente, no desmonte dos mecanismos articuladores da ação estatal.

A partir daí, tivemos miniciclos inconsistentes de crescimento, que desaguaram: no desapossamento do patrimônio público (e seu reapossamento pelo setor privado), que tinha sido construído em meio século de lutas e crescimento; na crítica quase generalizada ao Estado "interventor"; e, em suma, na reacomodação e cristalização dos velhos compromissos do amplo arco de alianças conservadoras que dominam o núcleo do poder no Brasil.

Em vinte anos, desde a crise de 1983 até 2002, as temáticas dos problemas urbanos clássicos (habitação, transporte, saneamento etc.) peram1 "No período 1940 a 1970 a população urbana braseira quase triplicou. De 1950 a 1960 aumentou $60 \%$ e de 1960 a1970, 65\%. De 1970 a 1980, a população urbana das cidades com mais de 20 mil habitantes aumenta de 37 milhões para 60,7 milhões, ou seja, houve um aumento de $60 \%$ (...) O aumento médio da taxa de urbanização de 1970 a 1980 foi de $111,53 \%$ e de 1980 a1990 foi de 107,66\%" (Souza, 1999, p.125). 
bularam por 19 órgãos diferentes, recebendo um tratamento compartimentado, tecnicista, fragmentado e pouco aderente à realidade de nossa sociedade urbana.

O fato é que se acelera a perda de poder orgânico e sistêmico do Estado brasileiro. Este perde poder de orientação e de promoção de renovadas frentes de expansão, periféricas ou mesmo "dentro do núcleo central". Vai erodindo aquela que é uma das principais marcas do capitalismo brasileiro: em que o processo das decisões de inversão de capital era amparado por ampla capacidade de coordenação das decisões públicas e privadas.

Paradoxalmente, este é o momento de auge da organização dos movimentos sociais que empunham a bandeira da reforma urbana, com o apoio da igreja católica progressista e do novo sindicalismo.

Contra toda sorte de "somatória de extorsões" (Kowarick, 1979) que as espoliações socioterritoriais impõem às populações de menor renda em sua reprodução, acumularam-se contrarreações que com a emergência de forças emancipatórias, reivindicativas e insurgentes são experimentadas na escala do lugar, buscando a justiça espacial.

Algumas prefeituras e membros dos parlamentos municipais do campo democrático-popular foram eleitos e experimentaram formas de governo mais participativas, embora em ambiente de forte restrição de recursos, em momento de profunda crise. Um ponto importante que fica cada vez mais claro no longo percurso histórico é que

a transição da ditadura para a democracia não significou a derrocada das forças po-
líticas que estavam no poder. Por mais que novos atores - como movimentos sociais
urbanos (entre eles os de moradia) e o novo movimento sindical - tenham entrado em
cena por meio de novos partidos e participado cada vez mais nos órgãos legislativos
e executivos no nivel local, os lideres dos antigos partidos e das antigas oligarquias
ainda detinham grande influência e controle político. (Rolnik, 2015, p. 268).

Desse modo, sobretudo na segunda metade dos anos 1980, as forças sociais e políticas da redemocratização impuseram importantes progressos durante o processo constituinte, destacando o princípio da função social da propriedade privada da terra.

Assim, 1988 pode ser considerado paradoxalmente um marco, tanto da Constituição cidadã, que estabeleceu importantes direitos sociais, quando da consagração da hegemonia das práticas, das narrativas e da remontagem de instrumentos e dispositivos neoliberais.

Faltavam 22 anos para terminar o século XX, quando, além da consagração de direitos e garantias individuais e de direitos coletivos, a promulga- 
ção da nova carta magna deixou uma grande expectativa de futuro avanço em uma abordagem territorial estrutural de nossas desigualdades.

Evoluiu-se na institucionalização de um Estado Democrático de Direito, ampliando a participação popular. Explicitaram-se conceitos e preceitos centrais para a estruturação dos fundamentos institucionais, financeiros e de proteção social de um Estado de Bem-Estar Social no Brasil.

\begin{abstract}
a garantia da existência digna por meio da homogeneização social (no sentido de Furtado: satisfação de necessidade e acesso a bens e serviços) está também diretamente vinculada à democracia. Afinal, com a falta de homogeneidade social, inúmeros setores da população já não mais se identificam com a politica e o Estado. A cidadania, assim, não se limita aos direitos de participação política, inclui, também, os direitos individuais e, fundamentalmente, os sociais. A ideia de integração na sociedade é fundamental para a democracia, o que não ocorre em países como o Brasil. A igualação das condições sociais de vida (...) é essencial para a legitimidade, permanência e futuro da democracia como forma política. (Bercovici, 2015, p. 79).
\end{abstract}

Em suma, contraditoriamente nesta década de 1980 há a convivência inusitada da energia e o ativismo dos movimentos, além de, simultaneamente, a crise profunda e a desmontagem das políticas públicas estruturais mais universalizantes. Há ainda a formação de uma nova paisagem institucional aderente às novas práticas neoliberalizantes de gestão, incorporando novos conceitos como governança, parcerias com o setor privado, confiscando e reconfigurando muitas das bandeiras marcantes da esquerda, como poder local, descentralização, participação social etc.

\title{
3 Os dois contextos regulatórios das questões urbana e regional no Brasil a partir do período pós-1990
}

Desde o final do século XX vão ocorrer no Brasil ações políticas conservadoras que pressionaram e lograram acumular força para prosseguir no desmantelamento agressivo do Estado, para em seguida fundar transformações no sentido da institucionalização política mais concertada do neoliberalismo, o que, adaptando a leitura de Leda Paulani (2013), poderíamos chamar de passagem da neoliberalização passiva para um processo de neoliberalização ativa.

Ingressamos definitivamente em um ciclo que vem sendo chamado de Regime Schumpeteriano de Workfare Pós-Nacional (SPWR) (Jessop, 2006; Brandão; Fernandéz; Ribeiro, 2017) em que a competitividade interurbana 
e inter-regional é o que conta no momento de cada cidade ou região propagandear suas vantagens comparativas para atrair investimentos e se destacar nas competições impostas pela guerra permanente entre os lugares.

As escalas urbana e regional no Brasil foram submetidas a exacerbadas rodadas de coerção concorrencial inter-municipalidades e à busca insana por demonstrar, no mercado de vantagens de cada cidade, sua competitividade urbana diferencial.

\subsection{Paisagem da reestruturação regulatória nos anos FHC}

No primeiro contexto regulatório, entre os anos de 1995-2002, do governo Fernando Henrique Cardoso, os processos de abertura comercial e financeira; o desmonte das capacidades estatais de intervenção; a entrega do patrimônio público à "iniciativa privada" (as vendas totalizaram cerca de 80 bilhões de reais, porém como seu deu por dispositivos ad hoc, como por exemplo a aceitação das chamadas "moedas podres" o Estado brasileiro recebeu apenas cerca de 10 bilhões em dinheiro, segundo alguns levantamentos); a internacionalização ainda maior de parcela fundamental do parque produtivo nacional culminaram, em 1999, com a instituição (nos últimos 18 anos) do tripé macroeconômico (metas de inflação, taxa de câmbio flutuante e metas de superávit fiscal primário). Instituído em 1999, o tripé foi fator decisivo para a manutenção de uma política ortodoxa, que impôs baixas taxas de crescimento ao país.

Um fato importante desse período foi, depois de 11 anos de tramitação parlamentar, a promulgação do Estatuto da Cidade, em 2001, que estabelece um conjunto de instrumentos que garantem a função social da propriedade e cria uma grande expectativa política sobre o avanço participativo dos Planos Diretores municipais.

Nesse mesmo ano, o governo extinguiu as superintendências de desenvolvimento regional (Sudam, Sudene etc.) tendo criado em substituição a Agência de Desenvolvimento da Amazônia - ADA e a Agência de Desenvolvimento do Nordeste - ADENE.

No plano da macroeconomia, as aberturas comerciais e financeiras determinaram importantes transformações nas relações das e entre as regiões brasileiras, e o aprofundamento da crise econômica e social nos espaços urbanos brasileiros, com destaque para suas maiores metrópoles. Assim, 
ao longo dos anos 1990, as mudanças nas paisagens urbanas e regionais brasileiras resultaram, em grande medida, de involuções e desconstruções, isto é, mais dos impactos diferenciados regionalmente, e em cada contexto urbano, da crise econômica e das opções conservadoras de políticas macroeconômicas, do que de processos reestruturantes.

Ocorreu re-especialização e re-mercantilização, pois o Brasil durante os anos 1990 aprofundou ainda mais suas vantagens históricas e competitivas estáticas e absolutas nos segmentos padronizados e de processamento contínuo de recursos minerais, florestais, energéticos, agrícolas e pecuários, como a produção de minério de ferro, siderurgia e alumínio (basicamente insumos metálicos semiacabados), petróleo e petroquímica, celulose e papel, alimentos industrializados (grãos, suco de laranja, carnes etc.) e têxteis padronizados.

Seguiu-se um processo de perda de participação e de desindustrialização na estrutura produtiva mais complexa e completa, no coração industrial do país (São Paulo e Sudeste); expansão do agronegócio exportador, com ocupação e urbanização acelerada do Centro-Oeste brasileiro; desmatamento da Amazônia, com poucas decisões de investimento em novas plantas produtivas.

A orientação macroestratégica por commodities e sua correspondente infraestrutura de logística está em elaboração e aperfeiçoamento desde a década de 1980 - ou mesmo antes, desde os "corredores de exportação de 1972" do governo militar - mas foi Eliezer Batista quem sintetizou os grandes eixos de crescimento do Brasil e da América do Sul, sob a encomenda do governo FHC.

A perda generalizada de dinamismo econômico e o alargamento dos desníveis socioeconômicos entre suas regiões foram determinados: pelo ambiente macroeconômico internacional; pelas opções equivocadas de política econômica; pela perda da qualidade sistêmica da atuação do Estado. Tudo isso resultou em disritmias entre os investimentos públicos e privados. Enquanto isso, a sociabilidade mediada meramente pelos valores mercantis foi aprimorando seus mecanismos (Mello; Novais, 2009). A crise urbana se agravou muito, inclusive com o aumento da violência, do desemprego, da precarização e da informalização do trabalho, com a periferização dos mais pobres se avolumando, ao mesmo tempo em que se promoviam grandes investimentos pontuais, gentrificações e ocorriam autossegregações das camadas sociais mais abastadas. 
A rodada de neoliberalização (Peck, 2010; Brenner; Peck; Theodore, 2012), com o manejo ortodoxo da política macroeconômica, aprofundou a crise e promoveu a financeirização do ambiente de decisões, com as convenções e o estado de confiança ficando abalados para direcionamentos de recursos para a criação de riqueza nova.

A partir desse momento, ficou mais clara a importância no capitalismo atual da mobilidade e difusão de Fast Policies, com a criação de toda uma infraestrutura de discussão, divulgação, circulação de conceitos, indicadores, catalogação e inter-referenciamento de best practices, treinamentos de comunidades práticas, consultores, promotora de experimentações tais como microcrédito, economia criativa etc. A partir dos centros hegemônicos e seus atores cosmopolitas, há a geração de desenhos e modelos institucionais codificados, que parecem "feitos para viajar", propícios a se adaptarem às circunstâncias locais e receberem suporte de parceiros específicos (Peck; Theodore, 2015).

As heterogeneidades inter e intra-regionais, sobretudo essas últimas, se aprofundaram. Ampliaram-se ilhas de produtividade e polos de competitividade, de produção e exportação de alguns produtos, em alta e vulnerável especialização regressiva. A guerra fiscal, enquanto estratégias agressivas de atração de investimentos, com a criação e aplicação de incentivos, muitos de natureza ad hoc e customizados, foi ampliando a coerção concorrencial entre os entes federativos. Com o acirramento das rivalidades inter-regionais e interurbanas, passa a se vender parcelas mais modernas e atrativas das cidades e regiões como inseridas nos contextos globais, enquanto se precarizavam ainda mais os outros espaços urbanos e regionais menos dotados de atratividade.

Nos dois mandatos do governo FHC, negligenciando políticas urbanas, foram definidos os ENIDs - Eixos Nacionais de Integração e Desenvolvimento-, que foram portfólios de oportunidades de investimentos de caráter estruturante, discutidos exaustivamente no Programa "Brasil em Ação" do PPA 1996/1999 e no Programa "Avança Brasil" do PPA 2000/2003 (Galvão; Brandão, 2003).

Em termos mais gerais, nos três entes do federalismo brasileiro, as instâncias de coordenação foram prejudicadas, o que fez com que prevalecesse uma perspectiva setorialista e compartimendora nas decisões públicas. As ações públicas se tornaram predominantemente setoriais e fragmentadas e orientadas pelo atendimento das demandas localizadas, clientelistas, circunscritas e de curto prazo. 
Deslegitimou-se totalmente o tratamento abrangente, e com continuidade planejadora, da questão regional e da questão urbana. Foi provocado no período, o travamento da capacidade institucional e financeira do Estado conceber e implementar políticas mais estruturadas.

Também no nível federativo intermediário, promoveu-se o enfraquecimento das instituições estaduais de pesquisa (FJP, FEE, IPARDES, SEI, Seade etc.), as quais tinham formulado importantes planos regionais e urbanos de desenvolvimento no passado, geralmente amparadas por seus respectivos bancos estaduais (BDMG, BASA, BNB (1952), BRDE etc.), que foram, em sua maioria, fechados nesse período.

A renegociação da dívida dos Estados e a entrada em vigor da Lei de Responsabilidade Fiscal (2000) vieram garrotear a capacidade estadual de planejamento e de levar a cabo políticas de combate às desigualdades regionais, com o desmonte do nível federativo intermediário.

Além da perda de substância e de legitimação do planejamento governamental, ocorreu o desmantelamento das instituições que deveriam cuidar dos problemas urbanos e regionais.

Em uma perspectiva mais estrutural de longo prazo, pode-se afirmar que, na dimensão espacial do nosso processo de subdesenvolvimento, esse período trouxe uma significativa mudança na articulação da diversidade regional e na dinâmica da urbanização. A partir do ajuste externo, do esforço exportador, além das privatizações, nega-se nossa herança histórica, em cada macrorregional, de montagem de estruturas produtivas relativamente complementares, com baixo grau de abertura para o exterior, e sob o amparo do Estado. Não apenas a situação econômica se agravou. Além do esgotamento do padrão de acumulação e de seu regime de regulação, ocorreram mudanças profundas no "padrão de sociabilidade", aumento da individualização, estancamento da mobilidade estrutural e intergeracional da "civilização brasileira". Ou seja, a mobilidade, que era uma das principais variáveis que fechava nossa equação social de legitimação do processo de expansão e crescimento econômico, mesmo com as brutais exclusão e modernização conservadora, foi travada. Acelera-se a crise fiscal e financeira do Estado brasileiro e o aniquilamento dos seus mecanismos de complexa e instável coordenação de interesses setoriais, sociais, urbanos e regionais. Ocorreram marcadas reatualizações e reposicionamentos: das heterogeneidades estruturais (produtivas, sociais e regionais); do pacto de dominação interna (e sua relação com o exterior); da sistêmica vulnerabi- 
lidade externa: da exclusão e marginalização da maioria da população dos frutos do progresso material, entre outros processos.

Assim, nos vinte anos desde a crise da dívida até o final do Governo FHC (1982/2002), as transformações do quadro regional e urbano brasileiro resultaram muito mais de forças inerciais, involuções e desconstruções do que de alguma decisão autônoma de mudança, ou de políticas institucionalizadas e explícitas.

\subsection{Paisagem da reestruturação regulatória nos anos do "Iulismo"}

O segundo contexto regulatório, aquele do período 2003-2015, foi marcado pela contradição, o chamado "lulismo" lançou mão de dispositivos, mecanismos e instrumentos bastante diferenciados e ambivalentes de experimentações re-regulatórias. Durante os governos Lula e Dilma reestruturações regulatórias de grande alcance foram implementadas em uma rodada de Roll-Out (Jessop, 2006; Brenner, 2004; Brandão, 2017a; Brandão; Fernandéz; Ribeiro, 2017), de re-regulação, reentrincheiramento, enfrentando modos de regulação anteriores e criando refúgios de defesa que mesclaram conformação aos mercados com defesa de alguns direitos sociais.

Ao mesmo tempo em que manteve, em linhas gerais, a política macroeconômica conservadora do tripé, aproveitou um ciclo muito favorável do ambiente externo para implementar a expansão do mercado interno e um conjunto de políticas sociais voltadas à proteção das camadas mais destituídas da população. Também iniciou o reaparelhamento dos quadros burocráticos do Estado e a concepção de políticas públicas de âmbito nacional.

Assim, tiveram início ações públicas destacadas em relação ao período dos anos noventa, mas tímidas frente à magnitude da marginalização social brasileira. Em poucos anos foi principiada a construção de uma plataforma social ou terreno de maior homogeneidade social, um patamar básico de cidadania, um colchão amortecedor e um chão de segurança social e de acesso a direitos individuais, que começou a proporcionar condições mais dignas de vida, com a satisfação das necessidades essenciais e a possiblidade de ingresso e integração na sociedade moderna por parte das massas historicamente destituídas dos frutos do progresso no Brasil.

A conjugação da valorização do salário mínimo, da maior formalização do mercado de trabalho, dos impactos dos Benefícios de Prestação Conti- 
nuada (BPC) para deficientes e idosos, das melhorias na previdência e assistência sociais rural e urbana, os programas sociais Luz para Todos, Cisternas; Pronaf e Minha Casa Minha Vida (MCMV), transformaram a vida cotidiana de algumas dezenas de milhões de pessoas, que foram incorporadas aos mercados capitalistas (de consumo, de trabalho, de moradia).

Caberia destacar, a expansão do ensino superior, o crescimento formal do emprego, a evolução das políticas de transferência de renda, a valorização do salário mínimo, a expansão do volume e das linhas de crédito e a luta pela permanência das conquistas e dos ganhos sociopolíticos da constituição cidadã. O papel dos bancos de desenvolvimento (BNDES, BDMG, $\mathrm{BNB}, \mathrm{BRDE}$ etc.) foi importante para sancionar decisões empreendedoras de capacidade produtiva nova. O país também progrediu em infraestrutura de estradas, portos, aeroportos e hidrelétricas, além de mais investimentos em ciência, tecnologia e inovação.

Durante tal período foram criados os Institutos Federais de Educação Tecnológica. Entre 2003 e 2016, foram construídas mais de 500 novas unidades referentes ao plano de expansão da educação profissional, totalizando 644 campi em funcionamento. Foram criadas 14 novas Universidades Federais. O número de municípios atendidos pelas universidades passou de 114 para 237. Desde o início da expansão, foram criadas mais de uma centena de novos campi para as universidades. Ou seja, um importante esforço de desconcentração, com a interiorização das Universidades Federais e dos IFETs, expansão e fortalecimento dos programas de pós-graduação nas regiões menos desenvolvidas desempenhou papel importante inusitado no período. O papel importante da CT\&I (Cavalcanti Filho, 2016) e a expansão dos campi universitários para as mudanças qualitativas na rede urbana brasileira (Vieira, 2017) requerem redobrado esforço de pesquisa hoje.

Em suma, a partir do Governo Lula, em 2003, mas, sobretudo no período de crescimento 2004/2008, uma série de políticas de desenvolvimento foram implementadas, mesmo que a política econômica tenha se mantido, em sua essência, de cunho ortodoxa.

Foram promovidos intentos de implementação de estratégias de cunho territorial e começou uma luta para buscar vencer o caráter setorial e fragmentado das políticas públicas.

O Ministério da Integração Nacional, que tinha sido criado em 1999, foi reestruturado e lançou, em 2003, a Política Nacional de Desenvolvimento Regional (PNDR), que foi aprovada em 2007, buscando privilegiar 
a atuação em uma escala sub-regional. A política seria erguida em torno do Fundo Nacional de Desenvolvimento Regional - FNDR, que deveria ter sido criado sob inspiração dos fundos estruturais e de coesão da política regional europeia. Em 2010, o governo apresentou o novo modelo de gestão da chamada PNDR - Fase II (2011-2015), que foi discutido entre o final de 2012 e o início de 2013 nas conferências estaduais, macrorregionais e na nacional, mas ainda não teve andamento sistemático. $\bigcirc$ próprio documento de referência preparado para a "I Conferência Nacional do Desenvolvimento Regional (2013)" elenca as principais limitações da trajetória da PNDR, dando destaque para o fato de não ter angariado apoio para ter centralidade política para ousar, e por ter caráter de política de Estado e não de um simples governo. Nem o FNDR foi criado, nem a sofisticada institucionalidade multiescalar e que tentava descompartimentar as ações no território avançaram (Brandão, 2018).

O Ministério do Desenvolvimento Agrário, criado em 1999, lançou em 2008, por meio de sua Secretaria de Desenvolvimento Territorial (SDT), o programa Território da Cidadania, que pretendia estabelecer uma estratégia de desenvolvimento territorial sustentável, elegendo 120 territórios como áreas prioritárias de ação.

Também foi criado o Ministério das Cidades, em 2003, que apresentou a Política Nacional de Desenvolvimento Urbano (PNDU), realizando as importantes conferências municipais, estaduais e nacionais de 2003, 2005, 2007, 2010 e 2013 a fim de definir as prioridades da política (Steinberger, 2013.).

Além do incentivo aos Planos Diretores e à qualificação técnica para as políticas urbanas, um marco importante do período foi o lançamento, no momento de aprofundamento da crise econômica, em 2009, do programa MCMV, detalhadamente analisado pela literatura especializada (Cardoso, 2013 e 2017; Maricato, 2015; Rolnik, 2015; Faria; Schvarsberg, 2011). programa promoveu a dinamização do setor de construção civil e a geração de emprego e renda, por outro lado, exponenciou os preços dos imóveis e contribuiu para a segregação socioespacial. Como no passado, as chamadas políticas urbanas (no âmbito do BNH e do MCMV), ao fim e ao cabo, demonstraram ter sido muito mais inseridas no contexto de políticas macroeconômicas do que de provisão de moradias.

O avanço dessas políticas públicas, mesmo muitas vezes parciais ou inconclusas, foi central para o recuo da desigualdade. Constatou-se a redu- 
ção da desigualdade com intencionalidade política (Arretche, 2015), com o recuo das iniquidades e o maior acesso a serviços e bens, mudanças promovidas também com o aproveitamento do ciclo de crescimento que a economia internacional estava vivendo naquele momento.

Com o boom de commodities, a partir do "efeito China", uma profunda especialização regressiva foi encorajada, trazendo à baila as problemáticas mais marcantes e recorrentes de nossa experiência histórica, com enorme dificuldade de superar o caminho de menor resistência das vantagens comparativas estáticas e não-construídas e da inserção passiva e subordinada no contexto das hierarquias da escala mundial. Aprofundamos essa especialização, reforçando nossa "vocação" para a extração e a exploração dos recursos minerais, agrícolas e energéticos e nossa submissão na escala mundial aos centros hegemônicos.

Em um horizonte temporal mais largo, como o que tentamos esboçar neste texto, há que se ressaltar a natureza estrutural, ciclicamente reposta, desse processo de "desenvolvimento", dependente e periférico, que concentra em restrita porção territorial grande parte da riqueza e da pobreza nacional. Nesta segunda metade da segunda década do século XXI pode-se prospectar o aumento da cumulatividade e da inércia nos territórios já bem-dotados de investimentos, com tendência a forte processo de reconcentração espacial no "mundo regional" Sul-Sudeste-Litoral, que denominamos de Capitalismo Sul Atlântico Brasileiro.

Sobretudo nesse território de concentração metropolitana da costa brasileira os problemas socioespaciais se acumulam sem a articulação institucional federativa e sem a mobilização de instrumentos para a sua solução (violência, deficiências de serviços básicos, infraestrutura etc.). Recentemente, foi instituído o Estatuto da Metrópole (Lei n ${ }^{\circ}$ 13.089, de 12 de janeiro de 2015), que estabelece diretrizes gerais para o planejamento, gestão e execução das funções públicas de interesse comum em regiões metropolitanas, as quais apresentam insuficiências diversas para o tratamento adequado de problemática tão complexa no contexto de nosso pacto federativo.

Agora, com uma terceira rodada re-regulatória em 2016 tendo ocorrido, promovida de forma antidemocrática, torna-se imprescindível para a história do país realizar um balanço detalhado dos resultados, impasses e ausências daquelas políticas territoriais concebidas e, em grande medida, não implementadas no período do lulismo. Embora com pouco tempo para consolidar esses processos de transformação, pois tratam-se, em sua 
maioria, de fenômenos ainda em curso, é preciso buscar aquilatar, em uma visão de conjunto, as mudanças ocorridas e promover uma avaliação mais profunda, realizando um balanço do papel desempenhado pelas políticas públicas (produtivas, sociais e infraestruturais). Já no contexto territorial vis-à-vis, o cumprido pelo avanço e aprendizado conceitual das políticas explícitas de desenvolvimento regional devem ser avaliados. Foram políticas públicas setoriais, implementadas na escala nacional, e não explicitamente de cunho regional, que tiveram impactos importantes para a maior homogeneização social e a melhoria das condições de vida da população, justamente nos territórios caracterizados por menor crescimento econômico.

As assimetrias interpessoais diminuíram, enquanto as iniquidades inter-regionais brasileiras persistiram. A crise e os conflitos urbanos se mantiveram sem tratamento estrutural e sem o enfrentamento dos mais poderosos interesses privados. As questões urbana e regional, problemáticas intrinsecamente de longo prazo e com a mediação requerida no seio do Estado, ainda não foram adequadamente apropriadas ou legitimadas politicamente para enfrentar a envergadura e a complexidade da tarefa de seu tratamento e resolução.

O certo é que persiste o grande desafio no Brasil de instituir um planejamento territorial que construísse vetores estratégicos os quais permitissem engendrar impulsos dinâmicos de forma a gerar maior convergência de renda, alargamento de oportunidades e um processo paulatino de coesão (econômica, social, política) entre nossas heterogêneas regiões e que, conjuntamente, respeitasse e valorizasse nossa diversidade.

No caso do Brasil, há enorme dificuldade do Estado e do pacto federativo para se promover uma abordagem estrutural dos problemas regionais e fazer cumprir o princípio constitucional da redução dos desbalanceamentos inter e intra-regionais. Também há poderosos interesses estruturados, com representação nas prefeituras, câmaras de vereadores e assembleias, que não deixam prosperar as reformas agrária e urbana.

Um ponto importante do diagnóstico atual das novas dinâmicas regionais e urbanas seria procurar entender as diversas dimensões dos impactos econômicos, sociais e ambientais de ser ter em todo o território nacional um conjunto de obras interrompidas, inauguradas "pela metade", ou não concluídas ou mesmo abandonadas. Muitas expectativas de desenvolvimento regional foram frustradas. Além disso, impactos negativos estão presentes em sua maioria nas áreas dos grandes projetos descontinuados. 
Há uma carteira de investimentos em infraestrutura que atravessou governos de diversos matizes, algumas obras são reivindicações regionais das décadas de 1960, estiveram presentes nos "corredores de exportação" (1972), ENIDs e depois no PAC. O país não realizou uma reflexão mais profunda se algumas dessas obras talvez não façam mais parte de uma estratégia de inserção nos paradigmas tecnoeconômicos do século XXI.

É importante realizar uma investigação minuciosa sobre a natureza da reprodução da força de trabalho hoje, nos meios rural e urbano. O mercado de trabalho se reestruturou e ampliou sua formalização, embora em termos qualitativos tenha deixado a desejar, gerando, em sua maioria, postos de baixa remuneração em serviços domésticos, construção civil, segurança privada, entre outros.

O modelo de consumo de massas, concebido em 2003 e subjacente a vários documentos oficiais, propugnava que o aumento da demanda popular por bens e serviços tradicionais e modernos iria redundar em uma onda de investimentos em capacidade produtiva nova e regionalizada, ampliando a produtividade e a competitividade nos mercados externos, mas isso não foi confirmado.

Quando do processo recente de crescimento, entre 2004 e 2010, poderiam ter sido mais acionados, apoiados e articulados setores e segmentos prioritários de grande capilaridade espacial, ligados aos complexos de saúde, educação, habitação, saneamento, transporte urbano, recursos hídricos, energias renováveis, agricultura e processos produtivos de baixa intensidade de uso de recursos naturais e energia. Não se logrou estancar a desindustrialização, muito menos promover transformações nas estruturas produtivas regionais, não possibilitando assim maiores transformações nas estruturas de distribuição de renda, muito menos se mexeu com propriedade e riqueza em regulações re-redistributivas de substância.

Desde o "Estudo da Dimensão Territorial do Planejamento" MPOG/ CGEE (2008), ganhou espaço a ideia de promoção, por meio da intencionalidade pública, de um Brasil mais policêntrico, em que

a rede de novas centralidades e a infraestrutura, especialmente do sistema de transportes, funcionariam como as bases para a integração territorial, econômica, social e política do país e para um melhor ordenamento do seu território. A rede urbana e a infraestrutura formariam as bases para uma nova política regional. A essas deveriam ser adaptadas as politicas tecnológicas, industrial, agropecuária, de serviços públicos e de outras atividades que se ajustariam segundo as intencionalidades politicas e econômicas de cada território e de seus agentes. (Diniz, 2013, p. 27). 
Seria necessário para o desenvolvimento econômico que as inversões de capital que ocorreram promovessem mudanças estruturais, tendo não apenas potência em termos de quantidade, mas antes de tudo de qualidade, isto é, que gerassem encadeamentos intra e intersetoriais (intra e inter-regionais e intra e interurbanos também), impostos, empregos e divisas robustos e duráveis. Um balanço das relações e encadeamentos, utilizando-se os conceitos de inter-ramificações econômicas, inter-regionalidades e interurbanidades poderiam ajudar nesta análise (Brandão, 2011).

É preciso aprimorar a transversalidade nas políticas públicas para montar, desenvolver e coordenar equações financeiras científicas, tecnológicas, ambientais, educacionais, de CT\&I e políticas interfederativas que articulem e desenvolvam capacitações.

Durante o Governo Dilma, ocorreu uma inusitada, e ainda pouco compreendida, insurgência de lutas políticas por provisão massiva e de qualidade de mais adequados bens e serviços públicos, as Jornadas de Junho de 2013, momento em que ficou claro que

\section{boas condições de vida dependem, frequentemente, de politicas públicas urbanas - transporte, moradia, saneamento, educação, saúde, lazer, iluminação pública, coleta de lixo, segurança. Ou seja, a cidade não fornece apenas o lugar, o suporte ou o chão para essa reprodução social. Suas características e até mesmo a forma como se realizam fazem a diferença. (Maricato et al., 2013, p. 33).}

Os próximos anos serão de crises e conflitos urbanos e regionais, em um ambiente de baixo crescimento e sob possível regressão social e política, assim, resta realizar um balanço do passado recente e lutar por um futuro diferente da história aqui estilizada.

Seria desejável um amplo debate democrático sobre escolhas estratégicas que congregassem projetos exitosos ou com potencialidades portadoras de futuro, aglutinassem e dessem vazão a recursos dispersos em variadas fontes, promovessem capacitação de quadros técnicos administrativos e montasse novas engenharias financeiras de horizonte temporal mais amplo. Também seria importante realizar a aplicação seletiva de recursos em pacotes de investimento realmente impactantes em termos de encadeamentos e de sustentação dos mercados domésticos/internos de cada região, além de uma inserção mais soberana e dinâmica no mercado internacional.

É preciso desenvolver capacitação governativa para tornar rotina introjetada nos aparelhos estatais e sua burocracia o ato de tomar o território como lócus de confluência e convergência das ações públicas, a partir das ações já em andamento, procurando dar-lhes coerência e coesão. Prospectar 
e levar a cabo empreendimentos estruturantes, com capacidade de constituir ou reforçar eixos de sustentação para outro padrão de crescimento com maior inclusão social e regional. É necessário estabelecer e aprimorar estratégias mais coordenadas e com perspectiva de longo prazo, ao mesmo tempo agregar ações mais aderentes às especificidades locais/regionais.

Tudo isso tem que ser descortinado mantendo no centro da agenda o combate permanente a nossas recalcitrantes e estruturais desigualdades multidimensionais (sobretudo as sociais e regionais) e buscando o respeito, o afloramento e a valorização de nossas heterogeneidades e diversidades.

Em suma, construir institucionalidades, instrumentos, dispositivos e projetos que, de forma sistêmica, permanente e conjugada, combata nossas injustiças sociais e socioespaciais, amplie a homogeneização social e o acesso a bens, serviços e infraestruturas sociais, proporcione melhores condições de vida à maioria da população, orientados por uma perspectiva "mais macro" de enfrentamento das grandes questões estruturais da destituição e da descidadania "no atacado"; ao lado da implementação de um conjunto de políticas públicas dotadas de uma perspectiva diferenciada/ diferenciadora, "mais micro", "no varejo", aptas a captar especificidades dos plurais subespaços intramacrorregionais e intramesorregionais.

É urgente congregar e enfeixar projetos em andamento, incitar outros mais ousados e inovadores, dar coerência e estruturação em trajetórias exitosas, realizar a bricolagem de políticas setoriais especializadas e compostas a serem "empacotadas", a fim de se construir uma rota promissora mais permanente de desenvolvimento mais imune aos ciclos político-eleitorais. Ativar e mobilizar a diversidade, sendo sensível às diferenças, mas também promover a revelação e a exploração de potencialidades de ativos e capacitações ociosos ou adormecidos.

Sensíveis às formas específicas de reprodução social das práticas da vida cotidiana, no nível de análise fundamental da teia fina do tecido social, é importante se atentar para as práticas espaciais no contexto da esfera essencial imediata. Na cotidianidade enquanto lócus do pragmatismo, das carências e das preocupações, as respostas imediatas a situações singulares muito concretas são formuladas. Este plano do "mundo da vida", em que se tecem as intersubjetividades culturais e as expressões dos direitos e liberdades individuais, com suas demandas, muitas vezes do material imediato, e com suas lógicas próprias precisam estar visibilizadas nas estratégias de desenvolvimento. 
Tais estratégias devem ser construídas democraticamente, com capacidade de prospecção e de apreensão das especificidades sub-regionais, sem ser localista (Brandão, 2012), a partir de uma ação estatal consequente, participativa e com o resgate do planejamento e levando em consideração nossa complexidade federativa.

No momento, estamos envoltos em uma profunda rodada de neoliberalização, no Brasil e no mundo, o que lembra a frase de Celso Furtado, a qual aponta que, na ausência de estratégias estruturantes, há sempre o risco de apenas se seguir "o curso dos acontecimentos prefigurados pelo mercado" (Furtado, 1967, p. 143), ou, no máximo, como ele dizia, gerar o enriquecimento material sem o enriquecimento cultural (Brandão, 2013), simplesmente se conformando aos mercados e aos negócios privados e não promovendo a construção da nação. $O$ fato é que somos uma sociedade ainda pouco democrática, orientada pela extensividade, itinerância e pela fuga para a frente expansiva. Conjuntural e ciclicamente, frequentes disputas redistributivas desaguam em impasses sociopolíticos marcantes.

A luta por disputar projetos de espaços urbanos e regionais mais democráticos e adequados à vida social emancipatória, pautada pelo trabalho decente, moradia digna, mobilidade socioespacial, como direitos inalienáveis para todos seus cidadãos, deve ser uma constante, sobretudo nesta quadra histórica e neste ambiente de degradação política e social em que estamos mergulhados no momento.

Coloca-se a necessidade de lutar por alimentar certos desígnios utópicos que induzam a lutas por um "modo de urbanização civilizatório: justo e ecologicamente sensível em outros mundos urbanos possíveis" (Harvey, 2002 , p. 8). Fica o desafio de encontrar forças para desatar capacidades e potencialidades para construir

um mundo melhor do que aquele que herdamos (...) o direito à cidade é o direito
de mudar e reinventar a cidade de acordo com o que deseja o nosso coração (...) a
liberdade de fazer e refazer a nós mesmos e a nossa cidade é (...) um dos direitos
humanos mais preciosos e mais negligenciados (...) Talvez por essa razão intuiti-
va, ao longo de toda a sua história a cidade tem sido uma imensa demonstração
de desejos utópicos por um futuro mais feliz épocas menos alienantes (Harvey,
2016, p. 261).

Nesse sentido, a importância dos convites à utopia, que galvanizem lutas e grande imaginação social que sonhe e busque rupturas concretas com a realidade atual (Sousa, 2016). 


\section{Considerações finais}

Procuramos neste artigo abordar, em traços bastante largos, a estrutura e a dinâmica do processo de urbanização no Brasil, as variadas rodadas de experimentação regulatória e de tentativas de levar a bom termo a institucionalização de políticas e de estratégias de planejamento urbano e regional em escala nacional.

O processo de urbanização foi caracterizado como expansivo, de fuga para a frente, de rápida produção de espaços da destituição dos direitos e do bem-estar coletivo, com a ocupação de áreas irregulares, em ambiente de crescimento econômico rápido. Embora o Brasil tenha construído virtuosamente a articulação econômica, a integração dos mercados regionais, a unidade nacional e a modernização conservadora e acelerada dos espaços urbanos e regionais, todo o processo se deu sob um pacto de dominação ultraconservador, antidemocrático e antipopular.

Para a maior parte de sua população, é na cidade onde acontece a reprodução cotidiana da vida, que se realiza em uma sociabilidade altamente urbanizada e precarizada, que deveria dispor de direito a usá-la como bem entender e à justiça socioespacial mais ampla, com sanções institucionalizadas e regulação mais forte sobre aqueles que a controlam e a querem usar apenas privativamente para seus lucros. Entretanto o que se tem é a completa marginalização e a destituição da maior parte das massas populacionais redundantes, que estão depositadas nos espaços desurbanizados e sem urbanidade da cidade.

Há carências de toda ordem, que vão desde os problemas de degradação ambiental, falta de mobilidade urbana e precariedades do transporte de massas, déficit habitacional, entre outras mazelas.

Apesar de ter engendrado socioeconomias urbano-regionais e rurais bastante complexas e modernas, estas estiveram, e continuam estando submetidas à estrutura política arcaica deste pacto retrógrado, que soldou alianças políticas e um contrato social produtor de todas (e simultâneas) expressões de desigualdade.

O privilégio da órbita da circulação dos capitais e o controle inabalável da propriedade (rural e urbana) fundiária sempre costuraram as equações políticas e econômicas que produzem o espaço brasileiro.

Variadas tentativas de disciplinar e regular esse controle e a acumulação urbana especulativa tiveram pouco êxito. As mudanças nas paisagens 
institucionais em que se desenrolaram tentativas de sua regulação, fazendo uso de políticas urbanas e regionais, aconteceram sob uma legislação extremamente complexa e sofisticada, pouco aderente em relação à vida concreta das pessoas. A legitimação sociopolítica e a colocação dessas estratégias de intervenção nunca estiveram no centro da agenda política e nunca se transformaram em políticas de estado, apenas de alguns governos em dada conjuntura muito específica. Foi de baixa intensidade a regulação das forças sociopolíticas que controlam a propriedade da terra e a expansão urbana.

Com uma trajetória de criação de várias paisagens regulatórias e institucionais que buscaram soluções técnico-racionais descontextualizadas da realidade socioeconômica do brasileiro, frequentemente em cíclicas rodadas conjunturais, ocorre o esvaziamento político, financeiro e técnico das instituições urbano-regionais.

Ao mesmo tempo, os problemas socioespaciais se agravam e se disseminam pelo continental e heterogêneo território nacional. Nos últimos anos, os circuitos da acumulação urbana se modernizaram, conglomeraram e financeirizaram. Projetos de intervenção ganharam ainda mais as marcas de uma cidade para os negócios e os lucros, mais do que da qualidade de vida para as pessoas.

Durante todo o período analisado, lutas sociais de resistências e o ativismo dos movimentos sociais estiveram em ação e espera-se que devem se ampliar com os novos conflitos repostos e exacerbados na cena urbana atual e futura.

$\mathrm{Na}$ escala nacional, o momento é de recessão e de profunda crise institucional e política, gerando muitas incertezas quanto ao futuro, mesmo o mais próximo. O cenário mais provável é de profundos impactos socioespaciais colocados pela diminuição do papel indutor e coordenador do Estado, do aumento do desemprego, da interdição de direitos, do aprofundamento dos processos de privatização e da maior internacionalização e subordinação da economia brasileira.

Se no final dos anos 1970 ficou famoso o artigo sobre o ovo de Colombo de Chico de Oliveira (1978), estamos agora mais para o ovo da serpente do totalitarismo e da intolerância das forças ultraconservadoras, da fragmentação social, do individualismo, da despolitização e do caos social. $\mathrm{Na}$ cena urbana, posições mais radicalizadas tendem a se expressar de forma mais contundente no futuro próximo. O contraponto poderá vir das novas 
dinâmicas dos movimentos sociais por justiça socioespacial e da politização desses conflitos.

\section{Referências}

ARRETCHE, M. (Org.). Trajetórias das desigualdades: como o Brasil mudou nos últimos cinquenta anos. São Paulo: Editora da Unesp, 2015.

AZEVEDO, S.; ANDRADE, L. Habitação e poder: da Fundação da Casa Popular ao Banco Nacional da Habitação. Rio de Janeiro: Zahar, 1982.

BACELAR, T. Tendências do desenvolvimento regional recente no Brasil. In: BRANDÃO, C.; SIQUEIRA, H. (Orgs.). Pacto federativo, integração nacional e desenvolvimento regional. São Paulo: Editora Fundação Perseu Abramo, 2013.

BERCOVICI, G. A questão social, a Constituição de 1988 e os desafios do desenvolvimento. In: SOUZA, P. (Org.). Brasil, sociedade em movimento. São Paulo: Paz e Terra; Rio de Janeiro: Centro Celso Furtado, 2015.

BERCOVICI, Gilberto. Desigualdades regionais, estado e constituição. São Paulo: Max Limonad, 2003.

BOLAFFI, G. Habitação e urbanismo: o problema e o falso problema. In: MARICATO, E. (Org.) A produção capitalista da casa (e da cidade) no Brasil industrial. São Paulo: Alfa Omega, 1979.

BRANDÃO, C. A. Dinâmicas e transformações territoriais recentes: o papel da PNDR e das políticas públicas não regionais com impacto territorial. Texto para Discussão. Brasília: IPEA, 2018. (no prelo).

BRANDÃO, C. A. Território e desenvolvimento: as múltiplas escalas entre o local e o global Campinas: Editora da Unicamp, 2012.

BRANDÃO, C. A. Territórios, escalas espaciais, decisões, poderes e conflitos. Campina Grande: Editora da UEPB, 2017b. (no prelo).

BRANDÃO, C. A.; FERNANDÉZ, V. R.; RIBEIRO, L. C. Q. (Orgs.). Escalas espaciais, reescalonamentos e estatalidades: lições e desafios para América Latina. Rio de Janeiro: Letra Capital, 2017.

BRANDÃO, C. Crise e rodadas de neoliberalização: impactos nos espaços metropolitanos e no mundo do trabalho no Brasil. Cadernos Metrópole, São Paulo, v. 19, n. 38, p. 45-69, jan./abr., 2017a.

BRANDÃO, C. Estratégias hegemônicas e estruturas territoriais: o prisma analítico das escalas espaciais. Bahia Análise \& Dados, Salvador, v. 21, n. 2, p. 303-313, abr./jun., 2011.

BRANDÃO, C. Prefácio. In: FURTADO, C. Essencial de Celso Furtado. São Paulo: Penguin/ Companhia das Letras, 2013.

BRENNER, N; PECK, J; THEODORE, N. Após a neoliberalização? Cadernos Metrópole, São Paulo, v. 14, n. 27, p. 15-39, 2012. 
BRITO, F. A transição para um novo padrão migratório no Brasil. Texto para discussão n. 526. Belo Horizonte: UFMG/CEDEPLAR, 2015.

BRITO, F.; PINHO, B. A. T. D. Distribuição espacial da população, urbanização e migrações internas no Brasil. Texto para discussão n. 524. Belo Horizonte: UFMG/CEDEPLAR, 2015.

CANO, W. Desconcentração produtiva regional do Brasil: 1970-2005. São Paulo: Editora da Unesp, 2008.

CARDOSO, A. L. (Org.). O Programa Minha Casa Minha Vida e seus efeitos territoriais. Rio de Janeiro: Letra Capital/Observatório das Metrópoles, 2013.

CARDOSO, A. L. et al. (Orgs.). Vinte e dois anos de política habitacional no Brasil: da euforia à crise. Rio de Janeiro: Letra Capital/Observatório das Metrópoles, 2017.

CASTRIOTA, R. Urbanização extensiva e planetária: formulações clássicas e contemporâneas. Dissertação (Mestrado em Economia), Centro de Desenvolvimento e Planejamento Regional, Universidade Federal de Minas Gerais, Belo Horizonte, 2016.

CAVALCANTI FILHO, P. F. O Nordeste na encruzilhada do desenvolvimento: a necessidade de constituição de um Sistema Regional de Inovação. In: MONTEIRO NETO, A.; CASTRO, C. N. BRANDÃO, C. A. (Orgs.). Desenvolvimento regional no Brasil: políticas, estratégias e perspectivas. Brasília: IPEA, 2016.

CHESNAIS, F. Finance capital today: corporations and banks in the lasting global slump. Boston: Leiden, 2016.

COSTA, G. M.; MENDONÇA, J. G. (Orgs). Planejamento Urbano no Brasil: trajetória, avanços e perspectivas. Belo Horizonte: Editora C/Arte, 2008.

DINIZ, C. C. Dinâmica regional e ordenamento do território brasileiro: desafios e oportunidades. Texto para discussão 471. Belo Horizonte: UFMG/Cedeplar, 2013.

FARIA, R.; SCHVARSBERG, B. (Orgs.). Políticas urbanas e regionais no Brasil. Brasília: Universidade de Brasília, FAU, 2011.

FARIA, V. Cinquenta anos de urbanização no Brasil: tendências e perspectivas. Novos Estudos, São Paulo, Cebrap, n. 29, março de 1991.

FARIA, V. O processo de urbanização no Brasil: algumas notas para seu estudo e interpretação. In: I ENCONTRO DA ABEP, Anais..., p. 89-110, 1978.

FIORI, J. L. O voo da coruja. Rio de Janeiro/São Paulo: Record, 2003.

FURTADO, C. Prefácio à nova economia política. Rio de Janeiro: Companhia Editora Nacional, 1967.

GALVÃO, A. C.; BRANDÃO, C. A. Fundamentos, motivações e limitações da proposta governamental dos "Eixos Nacionais de Integração e Desenvolvimento". In: GONÇALVES, M. F.; BRANDÃO, C. A.; GALVÃO, A. C. (Orgs.) Regiões e cidades, cidades nas regiões: o desafio urbano-regional. São Paulo: Editora da Unesp, 2003.

HARVEY, D. 17 contradições e o fim do capitalismo. São Paulo: Boitempo, 2016.

HARVEY, D. Cidades rebeldes: do direito à cidade à revolução urbana. São Paulo: Martins Fontes, 2014.

HARVEY, D. Do gerencialismo ao empreendedorismo urbano. In: HARVEY, D. A produção capitalista do espaço. São Paulo, Anablume, 2005. 
HARVEY D. Mundos urbanos possíveis. Novos Estudos Cebrap, São Paulo, n. 63, julho, pp.3-8, 2002.

JESSOP, B. ¿̀Narrando el futuro de la economía nacional e el estado nacional? puntos a considerar acerca del replanteo de la regulação e la re-invenção de la gobernancia. Documentos y Contribuições en Administração Pública y Gestão Estatal, v. 6, n. 7, p. 7-44, 2006.

KOWARICK, L. A espoliação urbana. Rio de Janeiro: Paz e Terra, 1979.

LOGAN, J. R.; MOLOTCH, H. L. Urban fortunes: the political economy of place. Berkeley, University of California Press, 1987.

MARCHI, M. A produção contemporânea do espaço urbano e o direito à cidade: um estudo sobre a inserção do programa Minha Casa Minha Vida na área conurbada de Florianópolis. Florianópolis, UFSC, PPG Geografia, Dissertação (Mestrado), 2015.

MARICATO, E. O impasse da política urbana no Brasil. Petrópolis: Vozes, 2011.

MARICATO, E. et al. Cidades rebeldes: passe livre e as manifestações que tomaram as ruas do Brasil. São Paulo: Boitempo, 2013.

MARICATO, E. Para entender a crise urbana. São Paulo: Expressão popular, 2015.

MARICATO, E. Politica habitacional no regime militar: do milagre brasileiro à crise econômica. Petrópolis: Vozes, 1987.

MELLO, J. M. C.; NOVAIS, F. Capitalismo tardio e sociabilidade moderna. São Paulo: Editora da Unesp, 2009.

MONTEIRO NETO, A.; CASTRO, C. N.; BRANDÃO, C. A. Desenvolvimento regional no Brasil: políticas, estratégias e perspectivas. Rio de Janeiro: IPEA, 2017.

MONTE-MÓR, R. L. Do urbanismo à política urbana: notas sobre a experiência brasileira. In: COSTA, G. M.; MENDONÇA, J. G. (Orgs). Planejamento urbano no Brasil: trajetória, avanços e perspectivas. Belo Horizonte: Editora C/Arte, 2008.

MPOG/CGEE. Estudo da Dimensão Territorial do Planejamento. Brasília: CGEE, 2008.

OLIVEIRA, F. Acumulação monopolista, Estado e urbanização: a nova qualidade do conflito de classes. In: MOISÉS, J. Á. et al. Contradições urbanas e movimentos sociais. Rio de Janeiro: Paz e Terra/CEDEC, 1978.

OLIVEIRA, F. Economia da Dependência Imperfeita. Rio de Janeiro: Graal, 1977.

OLIVEIRA, F. Prefácio. In: MARICATO, E. (Org.) A produção capitalista da casa (e da cidade) no Brasil industrial. São Paulo: Alfa Omega, 1979.

PAULANI, L Acumulação sistêmica, poupança externa e rentismo: observações sobre o caso brasileiro. Estudos Avançados, v. 27, n. 77, p. 237-261, 2013.

PECK, J. Novas direções em teoria urbana: para além da comparação? In: BRANDÃO, C. A.; FERNANDÉZ, V. R.; RIBEIRO, L. C. Q. (Orgs.). Escalas espaciais, reescalonamentos e estatalidades: lições e desafios para América Latina. Rio de Janeiro: Letra Capital, 2017.

PECK, J. Constructions of neoliberal reason. Oxford: Oxford University Press, 2010.

PECK, J.; THEODORE, N. Fast policies: experimental statecraft at the thresholds of neoliberalism. Minneapolis: University of Minnesota Press, 2015.

ROLNIK, R. Guerra dos lugares: a colonização da terra e da moradia na era das finanças. São 
Paulo: Boitempo, 2015.

SANFELICE, D. Financeirização e a produção do espaço urbano no Brasil: uma contribuição ao debate. Revista EURE, v. 39, n. 118, p. 27-46, set. 2013.

SOUSA, C. M. (Org.). Um convite à utopia. Campina Grande: EDUEPB, 2016.

SOUZA, M. A. O II PND e a política urbana brasileira: uma contribuição evidente. In: DEÁK, C.; SCHIFFER, S. R. (Orgs.). O processo de urbanização no Brasil. São Paulo: Fupam, Edusp, 1999, p. 111-143.

SPOSITO, M. E.; RIBEIRO, W. Perspectivas da urbanização: reestruturação urbana e das cidades. São Paulo: Expressão Popular, 2017.

STEINBERGER, M. (Org.). Território, estado e políticas públicas espaciais. Brasília: Ler Editora, 2013.

VIEIRA, D. J. Evolução do ensino superior brasileiro em período recente: novas perspectivas para o desenvolvimento regional? In: MONTEIRO NETO, A.; CASTRO, C. N.; BRANDÃO, C. A. (Orgs.). Desenvolvimento regional no Brasil: políticas, estratégias e perspectivas. Rio de Janeiro: IPEA, 2017.

VILLAÇA, F. Uma contribuição para a história do planejamento urbano no Brasil. In: DEÁK, C.; SCHIFFER, S. R. (Orgs.). O processo de urbanização no Brasil. São Paulo: Fupam, Edusp, 1999.

\section{Sobre o autor}

Carlos Antônio Brandão - brandaoufri@gmail.com

Universidade Federal do Rio de Janeiro, Rio de Janeiro, RJ.

Agradeço ao Conselho Nacional de Desenvolvimento Científico e Tecnológico (CNPq) pelo apoio a minhas pesquisas. Agradeço as observações dos pareceristas anônimos que apontaram importantes contribuições para a versão final.

\section{Sobre o artigo}

Recebido em 10 de março de 2017. Aprovado em 13 de junho de 2017. 